\title{
ARTICLES
}

Submitted 02.10.2014. Approved 09.12.2014

Evaluated by double blind review process. Scientific Editor: José Mauro da Costa Hernandez

DOI: http://dx.doi.org/10.1590/So034-759020150506

\section{DETERMINANTS OF THE SUCCESS OF GLOBAL AND LOCAL BRANDS IN LATIN AMERICA}

\author{
Determinantes do sucesso de marcas globais e locais na América Latina \\ Determinantes del éxito de las marcas globales y locales en América Latina
}

\begin{abstract}
The purpose of this paper is to address the issue of the implementation of global and local brands in Latin America by drawing on contingency theory to develop and test hypotheses relating to how product category characteristics affect the success of global and local brands in the region. Hypotheses are tested using data obtained from top brands rankings reported in five Latin American markets (Argentina, Brazil, the Caribbean and Central America, Chile and Mexico). The study design considers estimating a logistic regression on a binomial dependent variable measuring whether 475 top brands are global or local brands, with product category characteristics as independent variables. Results reveal that product categories related to subscriptions, local tastes, high-tech, and global citizenship do have an impact on the success of global and local brands in Latin America.
\end{abstract}

KEYWORDS | Branding, Latin America, local brands, global brands, product category.

\section{RESUMO}

O objetivo deste artigo é abordar da questão da implementação de marcas globais e locais na América Latina a partir da teoria da contingência, a fim de desenvolver e testar hipóteses relativas a como características de categoria de produto afetam o sucesso de marcas globais e locais na região. As hipóteses são testadas utilizando dados obtidos de rankings de marcas reportados em cinco mercados latino-americanos (Argentina, Brasil, Caribe e América Central, Chile e México). O desenho do estudo considera estimar a regressão logística em uma variável dependente binomial sobre se 475 marcas líderes são globais ou locais, tendo como variáveis independentes as características de categoria de produto. Os resultados revelam que categorias de produtos relacionadas a assinaturas, gostos locais, alta tecnologia e cidadania global efetivamente exercem influência no sucesso de marcas globais e locais na América Latina.

PALAVRAS-CHAVE I Branding, América Latina, marcas locais, marcas globais, categoria de produto.

\section{RESUMEN}

El propósito de este trabajo es abordar la cuestión de la aplicación de marcas globales y locales en América Latina mediante la elaboración de teoría de contingencia para desarrollar y poner a prueba las hipótesis relativas a cómo las características de la categoría de producto influyen en el éxito de las marcas globales y locales en la región. Las hipótesis se ponen a prueba utilizando datos obtenidos de rankings de marcas top publicados en cinco mercados de América Latina (Argentina, Brasil, el Caribe y América Central, Chile y México). El diseño del estudio considera la estimación de una regresión logística sobre una variable dependiente binomial midiendo si las 475 marcas top son marcas globales o locales con las características de la categoría de producto como variables independientes. Los resultados revelan que las categorías de producto relacionadas con las suscripciones, los gustos locales, la alta tecnología y ciudadanía mundial tienen un impacto en el éxito de las marcas globales y locales en América Latina.

PALABRAS-CLAVE / Branding, América Latina, marcas locales, marcas globales, categoría de producto. 


\section{INTRODUCTION}

In the 1990s, with increased globalization and the opening of bilateral trade agreements with other countries, the Latin American markets were enhanced with a huge number of products and brands available for sale. Currently, markets in the region are rapidly integrating across borders, and for many product categories, consumers are able to choose between global and local alternatives. Additionally, consumers in emerging countries are experiencing improved standards of living and lifestyle and exhibiting a desire to consume global brands (Bhardwaj, Park, \& Kim, 2011). It has been more than thirty years since Theodore Levitt (1983) wrote about global brands as the future of firm success. Global brands were supposed to sweep away national differences. However, they have not reached the promise that Levitt envisioned (Pitta \& Franzak, 2008). Although the automotive, computer, and electronics product categories, among others, are well-known for their strong global brands, many product categories are still characterized by their local brands in Latin America. Indeed, in most top brand rankings published by research agencies at the national level, top positions feature a mixture of global and local brands.

The process of internationalization implies a number of questions connected with brand management. Firms should organize their market entry strategy based upon brand equity resources (Johansson, Dimofte, \& Mazvancheryl, 2012; Kirk, Ray, \& Wilson, 2013; Lee \& Griffith, 2012). Managers confront difficult questions when developing the ideal brand portfolio. They must decide which brands to retain, and which to remove (e.g., global or local brands?) (Douglas, Craig, \& Nijssen, 2001). These are important decisions that significantly influence any firm's success (Chernatony, Halliburton, \& Bernarth, 1995; Douglas et al., 2001; Halliburton \& Hünerberg, 1993; Hollis, 2008; Kapferer, 2002; Kim \& Kim, 2005). Winit, Gregory, Cleveland, and Verlegh (2014) show that consumers evaluate global (vs local) brands more positively, regardless of brand ownership (local vs foreign). However, consumers may prefer either local or global brands, depending on contextual factors other than brand ownership, such as the particular product category. Whereas global brands may be preferred for some product categories, local brands may be favored for others. In fact, Winit et al. (2014) recommend that future research should consider an extended range of product categories in terms of their characteristics.

Whereas much research examines the relationship between brand origin perceptions and attitudes, few studies have focused on the roles played by product category characteristics on global/local brand evaluations and choice. Understanding variations in the success of global and local brands is important to academics focused on identifying their sources, and to managers whose branding strategies may depend on the extent of success of global and local brands within the product categories they manage. The purpose of this paper is to address the issue of the implementation of global and local brands by drawing on contingency theory to develop and test hypotheses relating to how product category characteristics affect the success of global and local brands. The findings of this study are of use to marketing managers in Latin America, whose branding strategies may partially depend on an understanding of the determinants of the success of global and local brands in the region. This research represents a novel attempt to incorporate product category characteristics as key factors affecting global versus local brand success. This research not only contributes to the extant literature, but also provides managerial implications by emphasizing that marketers must consider product category characteristics before selecting between global and local brands.

\section{CONCEPTUAL FRAMEWORK}

Figure 1 shows the conceptual framework for this study. The sources of global brand value and the processes through which global brands contribute to firm value differ systematically across product categories and brands (Bengtsson, Bardhi, \& Venkatraman, 2010; Steenkamp, 2014). Global and local associations operate in a manner very similar to brand associations in the transference of perceptions (Iversen \& Hem, 2011). A brand's perceived globalness had an important effect on consumer evaluation (Punyatoya, 2013). However, a wide range of contextual factors could exert influence on consumption choices and contribute to within-country heterogeneity (Douglas \& Craig, 2011). Consumers may prefer either local or global brands, depending on contextual factors such as the particular product-category. This section reviews the literature to derive hypotheses about the effects of product category characteristics on the success of global and local brands.

Firms in different industries show different levels of motivation for internationalization (Zeng, Zeng, Xie, Tam, \& Wan, 2012). It is possible that the success of global and local brands varies significantly when the type of product is considered. Schuling and Kapferer (2004) note that the push toward development of global brands has been driven more by supply-driven considerations linked to costs than by market considerations. In the 1980 s and 1990s, Japanese firms (e.g., Toyota, Panasonic) applied production quality controls and scale efficiencies to market standardized products across the world. American and European firms (e.g., Procter \& Gamble, Unilever, L’Oréal, Nestlé) transferred profit and loss responsibility from individual country 
managers to worldwide strategic business units, becoming truly global firms in the process (Quelch, 2003). When many firms went global, they took the products that were successful in their domestic markets and began selling them in foreign markets. Some were successful and quite literally created the product category in the host countries (Pitta \& Franzak, 2008). A key advantage of globalization is firms' opportunity to benefit from strong economies of scale. Standardized brands can generate significant cost reductions in all areas of the business system, including research and development, manufacturing, and logistics (Craig \&
Douglas, 2000; Levitt, 1983). However, many product categories such as hotels, electricity distribution, gas distribution, fast food restaurants, department stores, and supermarkets demand a strong local presence (e.g., buildings, production facilities, stores for operations). Consequently, significant opportunities could exist for local (vs global) brands in product categories that require a local presence, a local production. Hence:

$\mathrm{H}_{1}$ : Product categories that require a local production are positively associated with local brand success.

Figure 1. Conceptualization of the study

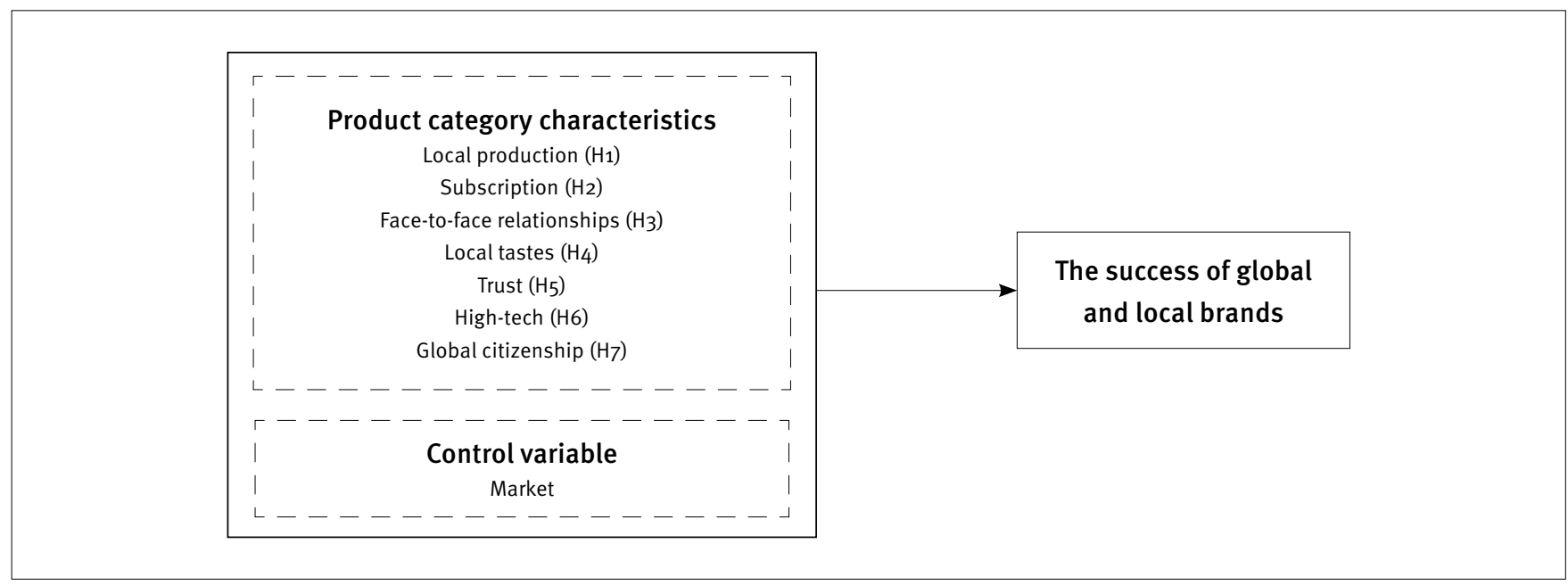

Factors influencing switching costs vary in accordance with the type of products. For consumers, switching costs include those that are monetary, behavioral, search, and learning related. When switching costs are substantial or the switching processes especially painful, dissatisfied customers are likely to maintain business relationships with existing service providers and resist the dissolution of the relationship. Schuling and Kapferer (2004) provide information on the usage of local and global brands. They show higher ratings for local brands (42.9\%) than for global brands (37.4\%). However, the usage intention indicates a different pattern: ratings are slightly higher for global brands (47.5\%) than for local brands (46\%). This might indicate that consumers are attracted to global brands but that, in reality, they buy local brands. This difference between usage and usage intention could be higher in product categories related to subscriptions (e.g., pension fund management, retail banking, and telecommunications services). The subscription is a business model where the customer must pay a subscription price to have access to the product/service. Generally speaking, these are product categories with which the customer, once a provider has been chosen, does not switch brands unless a specific action, which entails costs for both the firm (marketing effort) and the customer (e.g., psychological, financial costs), merits the switch (Hidalgo, Manzur, Olavarrieta, \& Farías, 2007; Venkatesan \& Kumar, 2004). Hence:

$\mathrm{H} 2$ : Product categories related to subscriptions are positively associated with local brand success.

Research in social psychology has identified cues of trustworthiness in face-to-face situations (e.g. eye contact, lateral flexion of head). Customers in several product categories tend to build a face-to-face relationship with the brand employees. In many product categories (e.g., airlines, health care services) local brands compete on the basis of well-established face-toface relationships with their customers (Dawar \& Frost, 1999). In several product categories, local brands represent many years of face-to-face relationships and customers have developed close relationships with these brands over the years. In these product categories, local brands hold important advantages, such as long-standing emotional links that represent a critical proximity to customer values (i.e., being a brand people grew up with) and high awareness levels (Kapferer, 2002; Wolfe, 1991). Hence: 
$\mathrm{H}_{3}$ : Product categories related to face-to-face relationships are positively associated with local brand success.

The signaling theory holds that by manipulating signals, firms use brands to inform consumers about product positions. Thus, local brands "signal" respect for and unique fit into cultural traditions, and pride in representing the local economy. Local brands are frequently seen as more authentic and down-to-earth, thus offering a more intimate basis for nurturing consumer-brand relationships. Local brands may be perceived as local icons, associated with local culture, tradition, and country (Winit et al., 2014). Local brands are not without their strengths, most notably, in their responsiveness to local needs, including those needs perhaps not precisely met by global brands (Schuling \& Kapferer, 2004), and by virtue of their close connection to the local cultural narrative (Steenkamp, Batra, \& Alden, 2003).

Culture, it seems, is harder to standardize than economic organization and technology. Consumers attribute personalities to brands that fit their own cultural values, not the values of the producer of the brand (Anand \& Delios, 2002; Becker-Olsen, Taylor, Hill, \& Yalcinkaya, 2011; Farías, 2007; Hofstede, 2001; Manzur, Uribe, Hidalgo, Olavarrieta, \& Farías, 2012; Mooij \& Hofstede, 2010). Several product categories as food (breakfast, meal solutions, frozen and fresh foods, snacks, cookies and candy), beer, media, and mineral water, could be local maybe because of a better response to local needs, flavors and tastes (e.g., advertisements, ingredients). The complexity of food, in particular, is noteworthy. Food preferences vary dramatically over the globe because of basic differences in local tastes, customs, and access to fresh, local products. It would be strange if curry powder, which is part of the Malay and Indian culture, were to use a "Western" brand name and image to make it more commercial. Generally, a product that is closely related to its culture must use local branding strategy (Douglas et al., 2001; Harun, Kassim, Igau, Tahajuddin, \& Al-Swidi, 2010; Kapferer, 2002; Wolfe, 1991). Hence:

$\mathrm{H}_{4}$ : Product categories related to local tastes are positively associated with local brand success.

The importance of the trust construct has already been demonstrated in sustaining buyer and seller relations. Trust is an attitudinal or mindset construct. It is the consumer's belief about whether or not the brand keeps its promises. Trust is defined as a willingness to rely on an exchange partner in whom one has confidence. Consequently, trust is a major determinant of relationship commitment (Moorman, Deshpandé, \& Zaltman, 1993). It represents the confidence that the relational party in an exchange will not exploit the other's vulnerability. Accordingly, to trust a brand implicitly means that there is a high probability or expectancy that the brand will result in positive outcomes for the consumer. A trustworthy brand is one that consistently keeps its promise of value to consumers through the way the product is developed, produced, sold, serviced and advertised. In Europe, Schuling and Kapferer (2004) documented that the image of trust is significantly stronger for local brands than for global brands (22.1\% vs. $17.9 \%$ ), and local brands (22.1\%) benefit more from a significantly stronger image of reliability than do global brands (17.9\%). Similarly, Pinar, Girard, and Eser (2012) show that brand image is significantly higher for local banks than for global banks. Trust reflects cumulative effects over time on loyalty in high-involvement, high-service product markets. Consequently, significant opportunities could exist for local brands in product categories that require image of trust (e.g., financial services, retail banking, nonprofit organizations, medicines, health care services). Therefore:

$\mathrm{H}_{5}$ : Product categories related to trust are positively associated with local brand success.

In China, consumers perceived global brands as high quality products, durable, innovative, and customer-oriented product design. Chinese consumers perceived local brands as low quality products, low trustworthiness issue, and poor product design (Ar \& Kara, 2012; Jap, 2010; Laforet \& Chen, 2012). Firms from emerging markets are not known for having the most innovative technology, superior human capital, or worldwide-recognized brands. They may also experience shortages of financial capital, which attenuates the implementation of marketing strategies (Magnusson, Westjohn, \& Zdravkovic, 2011; Wright, Filatotchev, Hoskisson, \& Peng, 2005). In Latin American countries, several studies have demonstrated that the brand is seen by customers as a sign of product quality, assisting them to make their purchasing decisions (e.g., Hidalgo \& Farías, 2006; Hidalgo et al., 2007; Lopes, Garcia, Santos, \& Schiavo, 2013; Manzur, Hidalgo, Olavarrieta, \& Farías, 2005, 2011; Merino \& Gonzalez, 2008; Milberg \& Sinn, 2008; Olavarrieta, Hidalgo, Manzur, \& Farías, 2006, 2012; Olavarrieta, Manzur, Hidalgo, \& Farías, 2008; Rojas-Méndez, Erenchun-Podlech, \& Silva-Olave, 2004; Torres, Hidalgo, \& Farias, 2007; Zanette, Lourenço, \& Brito, 2013). The electronics, computer, and automotive product categories have global brands, and these products appear to be more universal in terms of how they are used and how they are viewed. Computers and electronics, in particular, were also in earlier product life cycle stages when they became available around the world (Pitta \& Franzak, 2008). Jaffe and Martinez (1995) found that Mexicans rate American and Japanese electronic brands much more positively than Mexican electronic brands. Consequently, in Latin America 
small opportunities could exist for local (vs global) brands in high-tech product categories. Hence:

H6: Product categories related to high-tech are negatively associated with local brand success.

In the 1980s, technology opened borders digitally, if not physically, initially with satellite communication, then with wired and wireless transmissions. Media (e.g., television, newspapers, internet) showed lifestyles, reflecting a quality of life, inspiring a demand for something better (Pitta \& Franzak, 2008), and increasing similarity in lifestyles across the world (Alden, Steenkamp, \& Batra, 1999). A global identity means that consumers feel they belong to the global community and identify with a global lifestyle. Global brands carry an "exporting” culture, attract the "cosmopolitan" elite, and induce the aspiration to live in a global consumer community. Hall (1991) describes a growing global mass culture as driven by Western societies in terms of technology, capital, techniques, and advanced labor. With images and stories emanating from the West, this global mass culture "is centered in the West and it always speaks English" (Hall, 1991, p. 28). Hall fears that minority cultures or cultures in developing countries are likely to follow Western culture in the process of globalization (Maynard \& Tian, 2004). However, scholars have suggested that globalization is not necessarily a one-way process flowing from the West to the rest (Hamilton, 1994; Hofstede, 2001; Inglehart \& Baker, 2000). They argue that the development of a global economy does not lead to an increasing level of uniformity of Western culture across the world; instead, it contributes to the continual development of cultural diversity.

A single global brand name also provides the advantage of the development of a unique brand image across countries. It is especially important in certain product categories (e.g., alcoholic beverages, cereals, credit cards, clothing, fast food restaurants, jewelry and accessories, sportswear, tobacco), whose brands target worldwide segments of consumers, such as the teenager and affluent segments (Chu \& Huang, 2010; Hassan \& Katsanis, 1991; Strizhakova, Coulter, \& Price, 2012). In many product categories, perceived brand globalness could create consumer perceptions of brand superiority (Dahan \& Peltekoglua, 2011; Dimofte, Johansson, \& Ronkainen, 2008; Kapferer, 2004; Shocker, Srivastava, \& Ruekert, 1994; Strizhakova, Coulter, \& Price, 2011). Global brands are believed to enjoy greater esteem (Johansson \& Ronkainen, 2005) and evoke appealing global myths (Holt, Quelch, \& Taylor, 2004). Global brands are perceived to be more value-added for the consumer by enhancing the consumer's selfperception as being cosmopolitan, sophisticated and modern (Friedman, 1990; Holt et al., 2004; Johansson \& Ronkainen, 2005;
Kapferer, 2002; Steenkamp et al., 2003; Thompson \& Tambyah, 1999).

In developing countries, individuals associate global brands with having symbolic meanings, which enhances the emotional reward such as a sense of pleasure and happiness upon using these brands (Batra, Ramaswamy, Alden, Steenkamp, \& Ramachander, 2000; Bhat \& Reddy, 1998; Kinra, 2006). Findings also suggest that consumers in less developed countries associate global brands with an aspiration toward the lifestyles of more advanced economies (Alden et al., 1999). Consequently, in developing countries, a brand's country of origin not only serves as a "quality halo" or summary of product quality (Han, 1989), but also possesses a dimension of non-localness that, among some consumers and for some product categories, contributes to attitudinal liking for status-enhancing reasons (Batra et al., 2000). Hence:

$\mathrm{H}_{7}$ : Product categories related to global citizenship are negatively associated with local brand success.

\section{METHODOLOGY}

In Latin America, there were five studies that reported rankings of brands published over the past years. Such reports were used in our study - an attempt to obtain more recent ones was unsuccessful. Consequently, the present study includes the 100 top brands reported in Argentina (Centro de Estudios de Opinión Pública, 2009), the Caribbean and Central America (Fernández et al., 2009), Chile (TheLab Y\&R, 2010) and Mexico (Millward Brown, 2009), and the 75 top brands reported in Brazil (Sart Dreamaker, 2009), i.e., the analysis is set in the five largest Latin American markets.

Spanish is the main language in the majority of Latin American countries. Portuguese is spoken primarily in Brazil, where it is both the official and the national language. Consequently, for each top brand reported, three coders graduate students - fluent in Spanish and Portuguese, were instructed to code for the following items: global or local brand and product category (See Exhibit 1). A total of 39 product categories were used. These were: alcoholic beverages, airlines, beer, breakfast (excluding cereals), cars, cereals, credit cards, clothing, computers, conglomerates, department stores, electronics, energy distribution, fast food restaurants, financial services, frozen and fresh foods, health care services, home appliances, home care, hotels, internet websites, jewelry and accessories, meal solutions, media (television, radio, newspapers, magazines), medicines, mineral water, nonprofit organizations, pension fund management, personal care, soccer teams, soft 
drinks, snacks, cookies and candy, retail banking, sportswear, supermarkets, telecommunications services, tobacco, and other brick-and-mortar retailers. All disagreements in coding (overall agreement > 95\%) were discussed among the three coders, and a final consensus was reached (Szymanski \& Henard, 2001).

In order to examine the source of variations in the success of local and global brands, a detailed measurement of specific product category characteristics (local production, subscriptions, face-to-face relationships, local tastes, trust, high-tech, global citizenship) would be needed. These measures were obtained

\section{Exhibit 1.Variables}

\begin{tabular}{|c|c|c|}
\hline \multicolumn{3}{|c|}{ Dependent variable } \\
\hline Variable & Description & Examples \\
\hline $\begin{array}{l}\text { Local brand } \\
\text { success }\end{array}$ & $\begin{array}{l}\text { Top brand is a local brand } \\
\text { Global brands are those which are found in many countries } \\
\text { around the world, under the same name for the same product, } \\
\text { and typically operating under the same (or similar) positioning } \\
\text { strategy; whereas local brands are generally defined as those } \\
\text { available in one country or in a narrow geographical area (e.g., } \\
\text { Latin America), although these brands may be owned by a local, } \\
\text { international, or global firm. }\end{array}$ & $\begin{array}{l}\text { Banamex, Banorte, Claro, Coto, Cristal, Easy, Gol, } \\
\text { Golden, Jumbo, Líder, Luchetti, Pachuca, Pão de Açúcar, } \\
\text { Pilsener, Quilmes, Rede Globo, Swiss Medical, Vital }\end{array}$ \\
\hline \multicolumn{3}{|c|}{ Independent Variables } \\
\hline Variable & Description & Elements \\
\hline $\begin{array}{l}\text { Local } \\
\text { production }\end{array}$ & $\begin{array}{l}\text { It is strongly connected to local production (e.g., buildings, } \\
\text { stores, factories) }\end{array}$ & $\begin{array}{l}\text { Conglomerates, department stores, energy distribution, } \\
\text { fast food restaurants, health care services, hotels, } \\
\text { retail banking, supermarkets, telecommunications } \\
\text { services, other brick-and-mortar retailers }\end{array}$ \\
\hline $\begin{array}{l}\text { Face-to-face } \\
\text { relationships }\end{array}$ & $\begin{array}{l}\text { It is strongly connected to face-to-face relationships (social } \\
\text { interaction carried out without any mediating technology) with } \\
\text { the customers }\end{array}$ & $\begin{array}{l}\text { Airlines, department stores, fast food restaurants, } \\
\text { health care services, supermarkets, other brick-and- } \\
\text { mortar retailers }\end{array}$ \\
\hline Local tastes & $\begin{array}{l}\text { It is strongly connected to local tastes, local flavors, or local } \\
\text { needs. When consumer wants, uses, or responses to a product } \\
\text { vary with the market. }\end{array}$ & $\begin{array}{l}\text { Beer, breakfast (excluding cereals), clothing, frozen } \\
\text { and fresh foods, home appliances, home care, } \\
\text { internet sites, meal solutions, media (television, radio, } \\
\text { newspapers, magazines), mineral water, soccer teams, } \\
\text { soft drinks, snacks, cookies and candy }\end{array}$ \\
\hline $\begin{array}{l}\text { Global } \\
\text { citizenship }\end{array}$ & $\begin{array}{l}\text { It is strongly connected to globalization (interchange of world } \\
\text { views, products, ideas, and other aspects of culture) and } \\
\text { cosmopolitanism (all human ethnic groups belong to a single } \\
\text { community) }\end{array}$ & $\begin{array}{l}\text { Alcoholic beverages, cereals, credit cards, clothing, fast } \\
\text { food restaurants, jewelry and accessories, sportswear, } \\
\text { tobacco }\end{array}$ \\
\hline Market & Five markets (countries or economies) & $\begin{array}{l}\text { Argentina, Brazil, Caribbean and Central America, } \\
\text { Chile, Mexico }\end{array}$ \\
\hline
\end{tabular}

through three new coders - graduate students - as no secondary data sources comprehensively cover the large array of product categories included in this study (See Exhibit 1). For each product category, the coders were shown the name of the product category and a picture of a typical product. All disagreements in coding (overall agreement > 80\%) were discussed among the three coders, and a final consensus was reached (Szymanski \& Henard, 2001). Therefore, all variables used in this study were categorical measurements with two categorical levels. Table 1 provides a summary of the sample characteristics. 
Table 1. Data summary

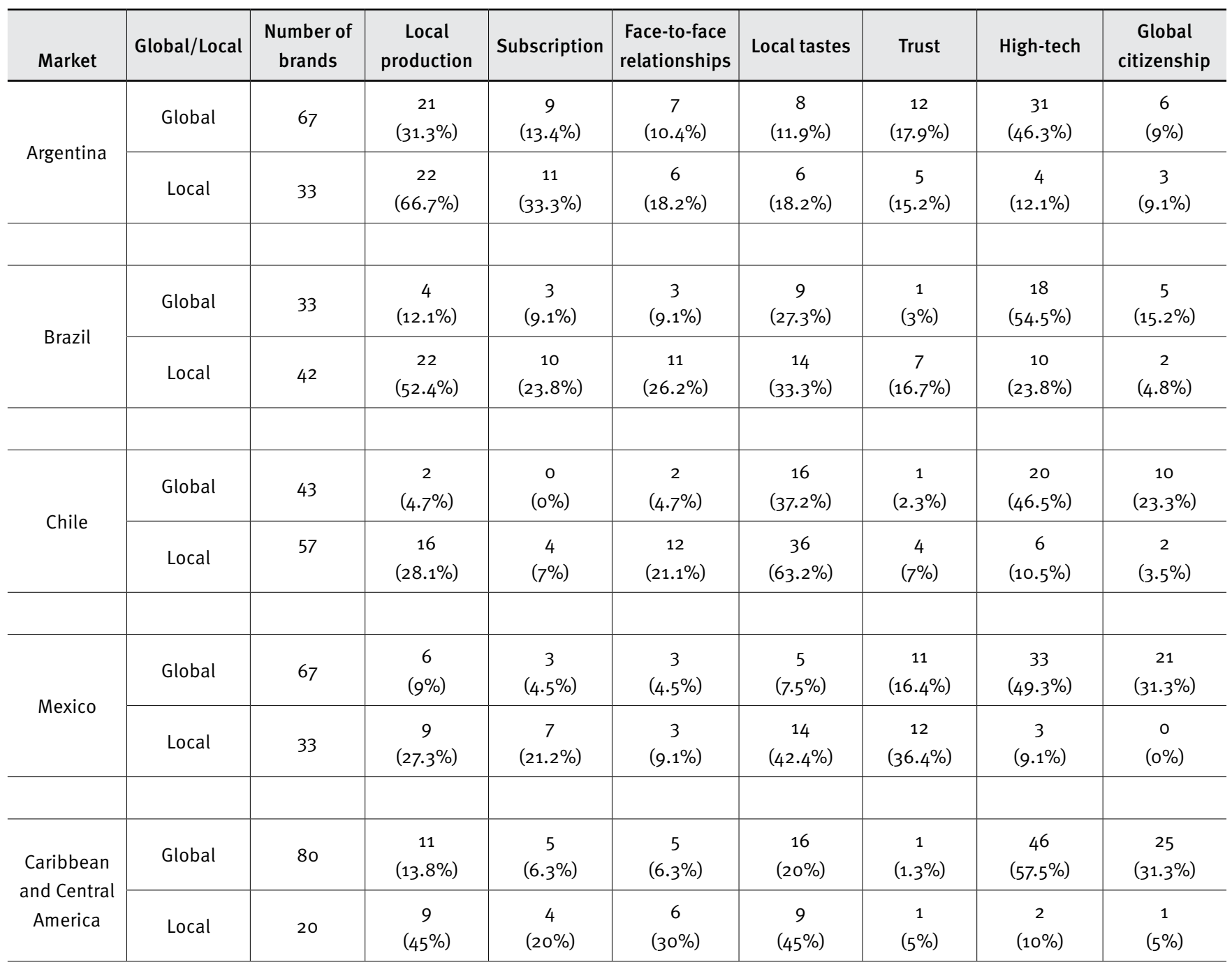

\section{RESULTS}

Discriminant function analysis is very similar to logistic regression, and both can be used to answer the same research questions. Logistic regression does not have as many assumptions and restrictions as discriminant analysis. Logistic regression is the common choice nowadays, since the assumptions of discriminant analysis are rarely met (Cohen, Cohen, West, \& Aiken, 2003). Consequently, in order to test the hypotheses, the study design considers estimating a logistic regression on a binomial dependent variable measuring whether top brands are global or local brands with product category characteristics as independent variables. Specifically, standardized regression estimates were obtained by regressing local brand success on the independent variables - local production, subscriptions, face-to-face relationships, local tastes, trust, high-tech, global citizenship, and the markets (Argentina, Brazil, Chile, Mexico) as control variables. A positive regression coefficient means that an increase in its associated variable will increase (decrease) the probability of local (global) brand success. On the other hand, a negative regression coefficient means that an increase in its associated variable will increase (decrease) the probability of global (local) brand success.

The parameters are estimated using maximum likelihood, employing the binomial logistic regression procedure of IBM SPSS Statistics 21. These are reported in Table 2. To begin, the variance inflation factors for each regression coefficient ranged from a low of 1.092 to a high of 3.012, suggesting that the variance inflation factors were at acceptable levels (Hair, Black, Anderson, \& Tatham, 2006). Since no particularly strong multicollinearity among the independent variables is found, all of them are included in the final model.

As can be seen, the overall regression is significant (Chisquare $($ d.f. $=11)=220.25, p<0.01)$. Product categories related to subscriptions and local tastes have a positive effect on local brand success $(\mathrm{p}<0.05)$. Therefore, $\mathrm{H}_{2}$ and $\mathrm{H}_{4}$ are supported. Product 
categories related to local production, face-to-face relationships, and trust have no effect on local brand success ( $p>0.05$ ). Thus, $\mathrm{H}_{1}$, $\mathrm{H}_{3}$ and $\mathrm{H}_{5}$ are not supported. Product categories related to global citizenship and high-tech are negatively associated with local brand success ( $\mathrm{p}$ < 0.01). Consequently, $\mathrm{H} 6$ and $\mathrm{H} 7$ are supported. These results reveal that while four product characteristics (subscriptions, local tastes, global citizenship and high-tech) do have an impact on the success of global and local brands, three product characteristics (local production, face-to-face relationships, and trust) have no effect on the success of global and local brands.

Although not the point of interest in this research, and considering the significance of significant values associated with Brazil and Chile ( $p<0.01$ ), perhaps an additional comment would be worthwhile about the meaning of these values. The results show that in Brazil and Chile there are significantly more local brands than in the Caribbean and Central America, Argentina, and Mexico. It seems that Mexico and the Caribbean and Central America have more global brands because of its proximity to the United States. Argentina has less local brands maybe because of the relative weakness of the local economy. In contrast, Brazil and Chile had more local brands, maybe because of the strength of their economies, which, in a way, provides for the creation and development of strong local brands.

The hypothesized model has a classification hit rate (percentage of correct classification) of $79.4 \%$ (See Table 3 ).
Press's Q Statistic is used to compare the number of correct classifications with the total sample size and the number of groups. As the value (163.88) exceeds the critical value (6.63), prediction accuracy exceeds the value assigned by chance. Consequently, the prediction accuracy is greater than that expected by chance. In the light of these test results, the hypothesized model appears to have satisfactory explanatory and predictive abilities.

The hypothesized model was compared to alternative models (considering interactions between product category characteristics and markets). The hypothesized model demonstrated a better model fit than the alternative models because results show no significant interaction effects between product category characteristics and markets, and chi-square and Nagelkerke's $R^{2}$ in the alternative models are slightly larger than that of the hypothesized model (Zheng, Yang, \& McLean, 2010). If there are no significant interaction effects, the hypothesized model could be valid for more than just Latin American countries. If the percentage of successful local brands in Brazil and Chile is greater than in Mexico, Argentina, and the Caribbean and Central America, but the factors that distinguish the success of each is the same in the five markets, maybe the results could be valid for other countries regardless of greater presence of local or global brands. Consequently, this article attempts to encourage similar research in other regions that confirms or refutes the results presented in this work.

Table 2. Logistic regressions of drivers of local brand success

\begin{tabular}{|c|c|c|c|c|}
\hline & Hypothesis & Estimate & Odds Ratio & $\mathrm{p}$-value \\
\hline Subscription & $\mathrm{H}_{2}:+$ & $1.932^{\star \star}$ & 6.904 & 0.000 \\
\hline Face-to-face relationships & $\mathrm{H}_{3}:+$ & 0.772 & 2.163 & 0.090 \\
\hline Trust & $\mathrm{H}_{5}:+$ & -0.078 & 0.925 & 0.866 \\
\hline High-tech & H6: - & $-2.066^{\star \star}$ & 0.127 & 0.000 \\
\hline Global citizenship & $\mathrm{H}_{7}:-$ & $-2.488^{\star \star}$ & 0.086 & 0.000 \\
\hline Chile & & $1.305^{\star \star}$ & 3.688 & 0.001 \\
\hline Mexico & & 0.623 & 1.864 & 0.144 \\
\hline Chi-square & $220.252^{\star \star}$ & & & \\
\hline Nagelkerke's $\mathrm{R}^{2}$ & 0.503 & & & \\
\hline
\end{tabular}

*Significant at $\alpha=0.05, * *$ Significant at $\alpha=0.01$. 
Table 3. Classification accuracy

\begin{tabular}{l|l|l|l|l}
\hline \multicolumn{5}{c}{ Forecast } \\
\hline Actual & $\begin{array}{l}\text { Local } \\
\text { brand }\end{array}$ & $\begin{array}{l}\text { Global } \\
\text { brand }\end{array}$ & Total & $\begin{array}{l}\text { Classification } \\
\text { accuracy }\end{array}$ \\
\hline Local brand & 131 & 54 & 185 & $70.8 \%$ \\
\hline Global brand & 44 & 246 & 290 & $84.8 \%$ \\
\hline Total & 175 & 300 & 475 & $79.4 \%$ \\
\hline
\end{tabular}

\section{DISCUSSION}

This paper examines the influence of product category characteristics on the success of global and local brands and tests the hypothesized relationships. Results show that the success of local brands is positively associated with subscriptions and local tastes. Also, results show that the success of local brands is negatively associated with high-tech and global citizenship. Whereas several studies have examined the relationship between brand origin perceptions and attitudes, few studies have focused on the roles played by product category characteristics on global/local brand evaluations and choice. This study is the first one that provides general support for the idea that the success of local and global brands in Latin America might depend on product category characteristics. Results of the empirical work presented here reveal a significant amount of local and global brand success variation across product categories. Understanding variations in the success of global and local brands is important to academics focused on identifying their sources, and to managers whose branding strategies may depend on the extent of success of global and local brands within the product categories they manage.

\section{Managerial implications}

The findings of this research are of use to managers in the region, whose branding strategies may partially depend on an understanding of the determinants of the success of global and local brands in Latin America. This research represents a novel attempt to incorporate product category characteristics as key factors affecting global versus local brand success. This research not only contributes to the extant literature, but also provides managerial implications by emphasizing that marketers must consider product category characteristics before selecting between global and local brands. Marketers should avoid assuming that the motives underlying global brand success are universal.
To date, there is a gap in the literature as to how global and local brands compete in Latin America. This study raises a number of important issues for marketing managers who are reluctant to expand abroad and compete with local or global brands, or who are struggling with their current globalization process. Diagnosing levels of local brand success and differences across product categories is important for managers who need to coordinate brands in a competitive multi-category environment. As such, this research addresses an important concern among researchers and managers regarding how to achieve the success of local and global brands in Latin America.

The findings indicate that the success of local and global brands in Latin America is product category-dependent. It follows that a firm's branding strategy should also be product categorydependent in the region. This work indicates that in product categories related to subscriptions and local tastes, significant opportunities may exist for local brands. In contrast, local brand success is significantly reduced in product categories related to high-tech and global citizenship. These results suggest that managers should not develop local brands in product categories closely related to high-tech and global citizenship.

The findings of this study provide the basis for several recommendations for international marketing managers in terms of the selection of product categories. Managers can use this knowledge by selecting product categories scoring high on hightech and global citizenship, and product categories scoring low on subscriptions and local tastes. These constructs, though related, exert independent influences. To identify appropriate product categories, each characteristic should be measured and assessed.

\section{Future research directions}

The findings of this study must be viewed in the light of its limitations. First, since this study involved only top brands, the findings may not be applicable to unknown brands. Future research should include more brands, and similar studies should be carriedout in other Latin American countries and/or other regions (e.g., Asia, Europe) to expand the applicability of the findings.

Second, studies that consider the success of global and local brands across different populations and consumer segments in Latin America (and other emerging economies) in order to check for demographic effects (e.g., age, gender, household income) might be another important avenue of research. Additionally, this study failed to identify any cultural factors that would moderate the effect of global and local brands. All consumers within a country are not identical. Indeed, there is substantial variation within a country, and also considerable overlap among different countries. Consumer differences should be incorporated into 
future research, as enduring brand loyalty, value consciousness, risk aversion, among others (Manzur, Olavarrieta, Hidalgo, Farías, \& Uribe, 2011).

Third, global firms routinely modify global brand strategies in individual country markets to balance cost-reducing standardization and relevance-maximizing localization (Cayla \& Eckhardt, 2008; Rigby \& Vishwanath, 2006; Spielmann \& Delvert, 2014). Therefore, further research using brand level data (e.g., branding strategies, advertisement investment) could complement this study.

Finally, this study relies on data from cross-sectional surveys, and in doing so assumes that there was no time lag between independent variables and the success of local and global brands. Consequently, this study does not completely cover the long-term effects of product category characteristics. Additionally, published top brand ranking studies only for the past years were considered. Although this allowed the study to be bound by contemporary evaluations, historical trends in brand positions may not have been captured. Therefore, further research using longitudinal data could complement this study.

\section{REFERENCES}

Alden, D., Steenkamp, J., \& Batra, R. (1999). Brand positioning through advertising in Asia, North America, and Europe: The role of global consumer culture. Journal of Marketing, 63(1), 75-87. doi: $10.2307 / 1252002$

Anand, J., \& Delios, A. (2002). Absolute and relative resources as determinants of international acquisitions. Strategic Management Journal, 23(2), 119-134. doi:10.1002/smj.215

Ar, A., \& Kara, A. (2012). Country of production biases on consumer perceptions of global brands: Evidence from an emerging market. Journal of Global Marketing, 25(3), 161-179. doi:10.1080/08911762. 2012.740155

Batra, R., Ramaswamy, V., Alden, D., Steenkamp, J., \& Ramachander, S. (2000). Effects of brand local and nonlocal origin on consumer attitudes in developing countries. Journal of Consumer Psychology, 9(2), 83-95. doi:10.1207/s15327663jicpoogo2_3

Becker-Olsen, K., Taylor, C., Hill, R., \& Yalcinkaya, G. (2011). A cross cultural examination of corporate social responsibility marketing communications in Mexico and the United States: Strategies for global brands. Journal of International Marketing, 19(2), 30-44. doi:10.1509/jimk.19.2.30

Bengtsson, A., Bardhi, F., \& Venkatraman, M. (2010). How global brands travel with consumers: An examination of the relationship between brand consistency and meaning across national boundaries. International Marketing Review, 27(5), 519-540. doi:10.1108/02651331011076572

Bhardwaj, V., Park, H., \& Kim, Y. (2011). The effect of Indian consumers' life satisfaction on brand behavior toward a U.S. global brand. Journal of International Consumer Marketing, 23(2), 105-116. doi:10 $.1080 / 08961530.2011 .543052$
Bhat, S., \& Reddy, S. K. (1998). Symbolic and functional positioning of brands. Journal of Consumer Marketing, 15(1), 32-43. doi:10.1108/07363769810202664

Cayla, J., \& Eckhardt, G. (2008). Asian brands and the shaping of a transnational imagined community. Journal of Consumer Research, 35(2), 216-230. doi:10.1086/587629

Centro de Estudios de Opinión Pública (2009). El ranking de imagen de marcas. Retrieved from http://www.ceop.com.ar/site/quienes_ ranking_marcas.asp

Chernatony, L., Halliburton, C., \& Bernarth, R. (1995). International branding: Demand or supply driven opportunity? International Marketing Review, 12(2), 9-21. doi:10.1108/02651339510089765

Chu, S. C., \& Huang, S. (2010). College-educated youths' attitudes toward global brands: Implications for global marketing strategies. Journal of International Consumer Marketing, 22(2), 129-145. doi:10.1080/08961530903476188

Cohen, J., Cohen, P. C., West, S. G., \& Aiken, L. S. (2003). Applied multiple regression/correlation analysis for the behavioral sciences (3rd ed.). Mahwah, NJ: Lawrence Erlbaum.

Craig, S., \& Douglas, S. (2000). Configural advantage in global markets. Journal of International Marketing, 8(1), 6-26. doi:10.1509/ jimk.8.1.6.19564

Dahan, G. S., \& Peltekoglu, F. B. (2011). The effects of Zara to the SMEs of an emerging market. Journal of Global Fashion Marketing, 2(1), 1-10. doi:10.1080/20932685.2011.10593077

Dawar, N., \& Frost, T. (1999). Competing with giants: Survival strategies for emerging market companies. Harvard Business Review, 77(2). Retrieved from https://hbr.org/.

Dimofte, C., Johansson, J., \& Ronkainen, I. (2008). Cognitive and affective reactions of U.S. consumers to global brands. Journal of International Marketing, 16(4), 113-135. doi: 10.1509/jimk.16.4.113

Douglas, S., \& Craig, S. (2011). The role of context in assessing international marketing opportunities. International Marketing Review, 28(2), 150-162. doi:10.1108/02651331111122641

Douglas, S., Craig, S., \& Nijssen, E. (2001). Integrating branding strategy across markets: Building international brand architecture. Journal of International Marketing, 9(2), 97-114.

Farías, P. (2007). Cambios en las distancias culturales entre países: Un análisis a las dimensiones culturales de Hofstede Opción, 23(52), 85-103.

Fernández, J. M., Medina, J., López, T., Flores, S., Ríos, B., \& Graciano, P. (2009, May-June). Las marcas más recordadas. Mercados \& Tendencias. Retrieved from http://revistamyt.com/

Friedman, J. (1990). Being in the world: Globalization and localization. Theory Culture \& Society, 7(2), 311-328. doi:10.1177/026327690007002018

Hair, J., Black, B. B., Anderson, R., \& Tatham, R. (2006). Multivariate data analysis (6th ed.). Upper Saddle River, NJ: Prentice-Hall.

Hall, S. (1991). The local and global: Globalization and ethnicity. In A. D. King (Ed.). Cultural, globalization and the world-system: Contemporary conditions for the representation of identity. Binghamton: State University of New York.

Halliburton, C., \& Hünerberg, R. (1993). Pan-European marketing: Myth or reality? Journal of International Marketing, 1(3), 243-249. 
Hamilton, G. (1994). Civilizations and organization of economics. In N. J. Smelser, \& R. Swedberg (Eds.). The handbook of economic sociology. Princeton: Princeton University Press.

Han, C. M. (1989). Country image: Halo or summary construct?. Journal of Marketing Research, 26(2), 222-229. doi:10.2307/3172608

Harun, A., Kassim, A., Igau, O., Tahajuddin, S., \& Al-Swidi, A. (2010). Managing local brands in facing challenges of globalization: $\mathrm{Be}$ a local or global leader? European Journal of Social Sciences, 17(2), $254-265$.

Hassan, S., \& Katsanis, L. P. (1991). Identification of global consumer segments: A behavioral framework. Journal of International Consumer Marketing, 3(2), 11-28. doi:10.1300/jo46vo3no2_03

Hidalgo, P., \& Farías, P. (2006). Analizando la compra de marcas privadas: Evidencia empírica desde Chile. Estudios Gerenciales, 22(101), 85-100.

Hidalgo, P., Manzur, E., Olavarrieta, S., \& Farías, P. (2007). Determinantes de la compra de marcas privadas. Revista de Ciencias Sociales, 13(2), 205-218.

Hofstede, G. (2001). Culture's consequences: Comparing values, behaviors, institutions, and organizations across nations (2nd ed.). Thousand Oaks, CA: SAGE Publications.

Hollis, N. (2008). The global brand: How to create and develop lasting brand value in the world market. New York: Milllward Brown.

Holt, D., Quelch, J., \& Taylor, E. (2004). How global brands compete. Harvard Business Review, 82(9). Retrieved from https://hbr.org/

Inglehart, R., \& Baker, W. E. (2000). Modernization, cultural change, and the persistence of traditional values. American Sociological Review, 65(1), 19-51.

Iversen, N., \& Hem, L. (2011). Reciprocal transfer effects for brand extensions ofglobalorlocalorigin: Evidencefrom Norway.International Marketing Review, 28(4), 365-411. doi:10.1108/02651331111149949

Jaffe, E., \& Martinez, C. (1995). Mexican consumer attitudes towards domestic and foreign made products. Journal of International Consumer Marketing, 7(3), 7-28.

Jap, W. (2010). Global brands vs. local brands in Chinese consumer mind. Journal of International Business and Economics, 10(2), 91-100.

Johansson, J., \& Ronkainen, I. (2005). The esteem of Global Brands. Journal of Brand Management, 12 (5), 339-354. doi:10.1057/palgrave. bm. 2540230

Johansson, J., Dimofte, C., \& Mazvancheryl, S. (2012). The performance of global brands in the 2008 financial crisis: A test of two brand value measures. International Journal of Research in Marketing, 29(3), 235245. doi:10.1016/j.ijresmar.2012.01.002

Kapferer, J. N. (2002). Is there really no hope for local brands? Journal of Brand Management, 9(3), 163-170. doi:10.1057/palgrave. bm.2540066

Kapferer, J. N. (2004). The new strategic brand management. London and New York: Kogan Page.

Kim, H., \& Kim, W. G. (2005). The relationship between brand equity and firms' performance in luxury hotels and chain restaurants. Tourism Management, 26(4), 549-560. doi:10.1016/j.tourman.2004.03.010
Kinra, N. (2006). The effect of country-of-origin on foreign brand names in the Indian market. Marketing Intelligence \& Planning, 24(1), 15-30.

Kirk, C., Ray, I., \& Wilson, B. (2013). The impact of brand value on firm valuation: The moderating influence of firm type. Journal of Brand Management, 20(6), 488-500. doi:10.1057/bm.2012.55

Laforet, S., \& Chen, J. (2012). Chinese and British consumers' evaluation of Chinese and international brands and factors affecting their choice. Journal of World Business, 47(1), 54-63. doi:10.1016/j. jwb.2010.10.020

Lee, H., \& Griffith, D. (2012). Transferring corporate brand image to local markets: Governance decisions for market entry and global branding strategy. In K. Scott Swan, Shaoming Zou (ed.) Interdisciplinary Approaches to Product Design, Innovation, \& Branding in International Marketing (Advances in International Marketing, volume 23). Emerald Group Publishing Limited.

Levitt, T. (1983). The globalization of markets. Harvard Business Review. Retrieved from https://hbr.org/

Lopes, E., Garcia, E., Santos, V., \& Schiavo, M. (2013). O novo consumidor idoso: Identificação dos atributos varejistas relevantes. RAE-Revista de Administração de Empresas, 53(6), 551-564. doi:10.1590/So034759020130604

Magnusson, P., Westjohn, S., \& Zdravkovic, S. (2011). "What? I thought Samsung was Japanese": Accurate or not, perceived country of origin matters. International Marketing Review, 28(5), 454-472. doi:10.1108/02651331111167589

Manzur, E., Hidalgo, P., Olavarrieta, S., \& Farías, P. (2005). Efecto de las características psicográficas en la intención de compra de marcas privadas en Chile. Revista Estudios de Administración, 12(2), 67-98.

Manzur, E., Olavarrieta, S., Hidalgo, P., Farías, P., \& Uribe, R. (2011). Store brand and national brand promotion attitudes antecedents. Journal of Business Research, 64(3), 286-291. doi:10.1016/j. jbusres.2009.11.014

Manzur, E., Uribe, R., Hidalgo, P., Olavarrieta, S., \& Farías, P. (2012). Comparative advertising effectiveness in Latin America: Evidence from Chile. International Marketing Review, 29(3), 277-298. doi:10.1108/02651331211229769

Maynard, M., \& Tian, Y. (2004). Between global and glocal: Content analysis of the Chinese web sites of the 100 top global brands. Public Relations Review, 30(3), 285-291. doi:10.1016/j.pubrev.2004.04.003

Merino, M., \& Gonzalez, S. (2008). Global or local? Consumers' perception of global brands in Latin America. Latin American Advances in Consumer Research, 2, 16-21.

Milberg, S., \& Sinn, F. (2008). Vulnerability of global brands to negative feedback effects. Journal of Business Research, 61(6), 684-690. doi:10.1016/j.jbusres.2007.06.045

Millward Brown (2009). Las mejores marcas en Mexico. Gestión de Negocios, 9(5), 12-73.

Mooij, M. De, \& Hofstede, G. (2010). The Hofstede model: Applications to global branding and advertising strategy and research. International Journal of Advertising: The Review of Marketing Communications, 29(1), 85-110. doi:10.2501/S026504870920104X

Moorman, C., Deshpandé, R., \& Zaltman, G. (1993). Factors affecting trust in market research relationships. Journal of Marketing, 57(1), 81-101. doi:10.2307/1252059

Olavarrieta, S., Hidalgo, P., Manzur, E., \& Farías, P. (2006). Riesgo percibido y la actitud hacia las marcas privadas. Revista Latinoamericana de Administración, 37, 73-89. 
Olavarrieta, S., Hidalgo, P., Manzur, E., \& Farías, P. (2012). Determinants of in-store price knowledge for packaged products: An empirical study in a Chilean hypermarket. Journal of Business Research, 65(12), 1759-1766. doi:10.1016/j.jbusres.2008.10.007

Olavarrieta, S., Manzur, E., Hidalgo, P., \& Farías, P. (2008). Un análisis a los atributos relevantes de los mercados de las pulgas para los compradores: Evidencia desde América Latina. Revista de Ciencias Sociales, 14(3), 468-478.

Pinar, M., Girard, T., \& Eser, Z. (2012). Consumer-based brand equity in banking industry: A comparison of local and global banks in Turkey. International Journal of Bank Marketing, 30(5), 359-375. doi:10.1108/02652321211247417

Pitta, D., \& Franzak, F. (2008). Foundations for building share of heart in global brands. Journal of Product \& Brand Management, 17(2), 64-72. doi:10.1108/10610420810864676

Punyatoya, P. (2013). Consumer evaluation of brand extension for global and local brands: The moderating role of product similarity. Journal of International Consumer Marketing, 25(3), 198-215. doi:10.1080/o 8961530.2013 .780857

Quelch, J. (2003, August). The return of the global brand. Harvard Business Review. Retrieved from https://hbr.org/

Rigby, D., \& Vishwanath, V. (2006). Localization: The revolution in consumer markets. Harvard Business Review, 84(4). Retrieved from https://hbr.org/

Rojas-Méndez, J., Erenchun-Podlech, I., Silva-Olave, E. (2004). The Ford brand personality in Chile. Corporate Reputation Review, 7(3), 232-251.

Sart Dreamaker (2009). As marcas mais influentes do Brasil. Retrieved from http://www.sart.com.br

Schuiling, I., \& Kapferer, J. (2004). Real differences between local and international brands: Strategic implications for international marketers. Journal of International Marketing, 12(4), 97-112.

Shocker, A., Srivastava, R., \& Ruekert, R. (1994). Challenges and opportunities facing brand management: An introduction to the special issue. Journal of Marketing Research, 31, 149-158. doi:10.1509/jimk.12.4.97.53217

Spielmann, N., \& Delvert, M. (2014). Adapted or standardized copy: Is non-cultural English the answer? Journal of Business Research, 67(4), 434-440. doi:10.1016/j.jbusres.2013.03.029

Steenkamp, J. B. (2014). How global brands create firm value: The $4 \mathrm{~V}$ model. International Marketing Review, 31(1), 5-29. doi:10.1108/imr10-2013-0233

Steenkamp, J. B., Batra, R., \& Alden, D. (2003). How perceived brand globalness creates brand value. Journal of International Business Studies, 34(1), 53-65. doi:10.1057/palgrave.jibs.8400002
Strizhakova, Y., Coulter, R., \& Price, L. (2012). The young adult cohort in emerging markets: Assessing their glocal cultural identity in a global marketplace. International Journal of Research in Marketing, 29(1), 43-54. doi:10.1016/j.ijresmar.2011.08.002

Strizhakova, Y., Coulter, R., \& Price, L. (2011). Branding in a global marketplace: The mediating effects of quality and self-identity brand signals. International Journal of Research in Marketing, 28(4), 342351. doi:10.1016/j.ijresmar.2011.05.007

Szymanski, D., \& Henard, D. (2001). Customer satisfaction: A metaanalysis of the empirical evidence. Journal of the Academy of Marketing Science, 29(1), 16-35.

TheLab Y\&R (2010). Las 100 mejores marcas de Chile. Revista Qué Pasa. Retrieved from http://www.quepasa.cl/

Thompson, C. J., \& Tambyah, S. K. (1999). Trying to be cosmopolitan. Journal of Consumer Research, 26(3), 214-241. doi:10.1086/209560

Torres, E., Hidalgo, P., \& Farias, P. (2007). Similitudes y diferencias en las causas psicográficas de la lealtad a la marca de producto y la fidelidad al supermercado?. Cuadernos de Administración, 20(33), 181-201.

Venkatesan, R., \& Kumar, V. (2004). A customer lifetime value framework for customer selection and resource allocation strategy. Journal of Marketing, 68(4), 106-125. doi:10.1509/jmkg.68.4.106.42728

Winit, W., Gregory, G., Cleveland, M., \& Verlegh, P. (2014). Global vs local brands: How home country bias and price differences impact brand evaluations. International Marketing Review, 31(2), 102-128. doi:10.1108/imr-01-2012-0001

Wolfe, A. (1991). The single European market: National or Euro-brands. International Journal of Advertising, 10(1), 49-58. doi:10.1080/0265 0487.1991 .11104433

Wright, M., Filatotchev, I., Hoskisson, R. E., \& Peng, M. W. (2005). Strategy research in emerging economies: Challenging the conventional wisdom. Journal of Management Studies, 42(1), 1-33. doi:10.1111/j.1467-6486.2005.00487.x

Zanette, M. C., Lourenço, C. E., \& Brito, E. P. Z. (2013). O peso do varejo, o peso no varejo e a identidade: Uma análise de consumidoras plus size. RAE-Revista de Administração de Empresas, 53(6), 539-550. doi:10.1590/s0034-759020130603

Zeng, R., Zeng, S., Xie, X., Tam, C., \& Wan, T. (2012). What motivates firms from emerging economies to go internationalization? Technological and Economic Development of Economy, 18(2), 280-298. doi:10.3846 /20294913.2012.677588

Zheng, W, Yang, B., \& McLean, G. N. (2010). Linking organizational culture, structure, strategy, and organizational effectiveness: Mediating role of knowledge management. Journal of Business Research, 63(7), 763-771. doi:10.1016/j.jbusres.2009.06.005 